\title{
HERPETIC PHARYNGITIS AND STOMATITIS. A REPORT OF THREE CASES
}

\author{
By PERRIN H. LONG \\ (From the Medical Clinic of the Johns Hopkins Hospital and the Department of Medicine, \\ Johns Hopkins University, Baltimore)
}

(Received for publication July 31, 1933)

In recent years great interest has been manifested in the virus of herpes simplex. It has been stimulated by an increasing curiosity regarding filterable viruses in general, and by the possibility that herpes virus may have a causal relationship to epidemic encephalitis. However, despite the enthusiasm for the study of the properties of this filterable agent, little attention has been paid to the natural manifestations of the disease herpes simplex. This may be due to the ubiquity of herpes simplex or it may be possible that the essential herpetic character of many affections is not recognized.

The recognition of herpes as a clinical entity is probably of great antiquity, the word itself being derived from the Greek " $\rho \pi \eta \eta$ meaning literally "a creeping." Aretaeus the Cappadocian, in discussing affections of the tonsils, describes small superficial ulcers to which he gave the name aptha. It is not unlikely that these lesions were herpetic in nature. In 1398, John Trevisia in his fragmentary translation of Bartholomaeus Anglicus' manuscript, "On the Property of Things," makes mention of "this euyll is callyd Herpes" and "suche a scabbe highte Herpes Cingula." This constitutes the first reference to herpes in the English language, and it is plain from this citation that herpes was recognized in the Middle Ages. During the succeeding centuries one finds a constant increase in the number of references to herpetic infections, thereby demonstrating the interest attached to the disease.

However, it was not until the beginning of the nineteenth century that a clear differentiation was established between the clinical course of herpes simplex and herpes zoster. Following this distinction one finds an increased interest taken by clinicians in the delineation of the various simple herpetic affections. The general manifestations of the disease, as well as the local, occupied their attention and in the middle of the century, several splendid clinical reports describing the disease are to be found.

Gubler (1) in 1858 gives an admirable account of herpetic infections of the throat which we will quote. "A la suite d'un refroidissement, un sujet est pris de malaise, de courbature, puis d'une fièvre quelquefois 
assez intense, ainsi que d'un mal de gorge: les deux amygdales sont tuméfiées, rouges et ne tardent par à présentes des surfaces circulaires ou irrégulièrement configurées, semblables à des ulcérations superficiells couvertes d'une exsudation plastique grisâtre ou jaunâtre; souvent cette dernière lésion est unilatérale. En même temps il apparaît sur les lèvres une éruption d'herpès ordinairement groupée en grand partie vers l'une des commissures. Tel est aussui le type consacré par le description classique. Eh bien, dans mon opinion, ces ulcérations tonsillaires doivent être considérées comme de l'herpès labialis sur une surface muqueuse."

Trousseau (2) devoted an entire clinic to the description of herpetic pharyngitis. His description of the individual lesions is classical. "On voit en effet des taches blanche, entourées d'une aréole inflammatoire assez étendue, et dont le volume varie depuis le groisseur d'un grain de millet jus qu' à celui d'un pois. Ces taches laissent à leur place des ulcérations superficielles dont les bords peuvent néanmoins être saillants en raison du gonflement oedémateux des tissus environnants envahis par l'inflammation."

In 1881 James Wilson in his book on "The Continued Fevers" describes simple continued fever as "a fever not due to any specific cause, usually of short duration, lacking the distinguishing characteristics of other fevers, and rarely fatal in temperate climates. . . . The eruption of herpes upon the lips and nose is so common at the close of simple continued fever that this disease by some persons has been called Herpetic Fever."

Two years later Savage (3) reported an epidemic of herpetic fever which occurred in an English boys' school. The clinical picture of the disease in this epidemic was characterized by a slow onset accompanied by headache, lassitude, chilliness, fever, irritability, malaise and vomiting. After twenty-four hours, patches of herpetic lesions appeared about the lips or lobes of the ears. In two individuals vesicles appeared on the lower extremities. With the appearance of the vesicles the patients complained of sore throats. Frequently herpetic lesions were present in the throat. By the fourth day the temperature was normal and the patients were convalescent. Thirty-nine boys were affected during a two-week period.

In recent years, despite Trousseau's remark that " $\mathrm{Au}$ jour d'hui qu' on est suffisamment averti, il est peu de médecins qui n'aient en l'occasion d'en observer des exemples," very little can be found in medical literature regarding the clinical course of localized and generalized herpetic infections of the simplex type. In 1932 Youmans (4) described an individual ill from herpetic fever with stomatitis. He was successful in isolating the virus of herpes simplex from the mouth lesions in this patient, thus for the first time demonstrating the essential etiological character of the disease. 
In this report we wish to discuss three cases of herpetic infections in the mouth, two of which were accompanied by fever. From two of the individuals the virus of herpes simplex was recovered.

\section{CASE HISTORIES}

Miss C. K., J. H. H. 40611, a student, aged 23, entered the Medical Clinic on December 9, 1931, complaining of a "sore throat and swollen tender gums" of three days duration. Her past and family history was unimportant. Three days before coming to the clinic the patient had spent the week-end in New York and while riding to Baltimore on the train, she noticed that her throat was sore. Upon the following day she experienced "chills and fever." The soreness in the throat increased and the gums became tender and swollen. Headache appeared and some generalized aching was present. On December 8 th the symptoms were more marked and the throat affection was so severe that swallowing became very difficult. She was admitted to the Isolation Ward on the following morning.

Physical examination. The patient was undernourished and seemed quite uncomfortable. The temperature was $101.6^{\circ} \mathrm{F}$., the pulse 112 , and the respirations were 20 . The skin was warm and moist, the ears, eyes and nose were normal. The lips were dry and cracked and just to the right of the midline was a small, crusted, superficial, ulcerated lesion. The gums were tender, swollen and spongy and there were numerous small superficial lesions capped with white membranes on the tooth-gum margins. These bled freely when slightly traumatized. Near the tip of the tongue were several small vesicles as well as upon the hard palate. The tonsils had been cleanly removed, but the soft palate, uvula, pillars and posterior pharyngeal wall were intensely inflamed and moderately swollen. The lymphoid follicles of the posterior pharyngeal wall were markedly hypertrophied and there were numerous small superficial vesicular lesions over the posterior pharyngeal wall. The regional lymph nodes were enlarged and slightly tender, as were also the axillary glands. The remainder of the physical examination was essentially normal.

Laboratory data. Urine, normal. Red blood cells 4.4 million. Hemoglobin 90 per cent. White blood cells 4,560. Differential count-Polymorphonuclears 72.5 , lymphocytes 12.5 , monocytes 15 . Wassermann reaction negative. Throat cultures (7), staphylococcus aureus. Throat smears-no Vincent's organisms. Blood culture negative.

Impression. It was thought on admission to the Ward that the patient was suffering from an acute septic sore throat and an aphthous stomatitis. The possibility of a Vincent's infection was considered, but at no time were Vincent's organisms demonstrated.

Course. The temperature remained elevated on the day after admission and the total white blood cells numbered 6,000. The patient complained of a severe sore throat. The mouth lesions were unchanged. On December 11th the temperature was lower and the white blood cells totaled 5,950. The white membranes capping the vesicles were beginning to slough off, leaving clean superficial ulcers. On December 12th the temperature fell to normal and there was a marked symptomatic improvement. White blood cells 3,750 . Treatment of the ulcers by topical application of 2 per cent gentian violet was instituted. During the next few days the patient improved and by December 18th her mouth and throat were free from ulcerated areas. On December 22nd she was discharged, well, and as far as we know, she has never had a recurrence of this affection. 
Mr. M. T., J. H. H. 46235, a white, night club saxophone player, aged 25 years, entered the Medical Clinic on November 4th, 1932, complaining of a "sore mouth" of six days duration. His past and family history was unimportant. Five days before coming to the hospital the patient felt "feverish" and thought that his tongue and gums were dry and swollen. A moderately severe headache was present. By evening he developed definite soreness of the throat, tongue and gums. On the following day he felt "grippy" and suffered from generalized aching and malaise. By the next day his throat was so sore and he felt so seedy that he took to his bed. Profuse sweats occurred, his neck became swollen and tender and his headaches more severe. He suffered from insomnia and on the night before entry he was disoriented. All of his symptoms increased in intensity and he came to the hospital.

Physical examination. The patient was well developed and well nourished, but apparently was very uncomfortable. The temperature was $100^{\circ} \mathrm{F}$., the pulse 96, and the respirations 22 . The skin was hot and dry, the ears, eyes and nose were normal. The lips were dry, fissured and scaly. Several small superficial crusted ulcers were present on the outer dry surface of the lips. The inner surface of the lips, the buccal mucous membranes, and the gums were dull red in color. Many deflated vesicles capped with dead white skin were seen on these surfaces. The gums bled when slightly traumatized. The tongue was beefy red and was covered with numerous vesicles. Many similar lesions were seen on the hard palate. The soft palate, uvula, pillars, and posterior pharyngeal wall were moderately inflamed and slightly swollen. On the soft palate, uvula and right posterior pillar there were small vesicles surrounded by a small area of intense hyperemia and capped with a dull chalk-white tense membrane. These collapsed completely when the vesicular fluid was released. The regional and anterior cervical lymph nodes were enlarged and tender. Otherwise the physical examination was normal.

Laboratory data. Urine normal. Red blood cells 4.6 million. Hemoglobin 106. White blood cells 6,880. Differential count-polymorphonuclears 62, eosinophiles 1 , basophils 1 , lymphocytes 34 , monocytes 2 . Wassermann reaction negative. Throat smears-no Vincent's organisms. Throat culture -staphylococcus aureus.

Impression. Because of the presence of typical herpetic lesions upon the lips and the vesicular character of the eruptions in the mouth, it was thought that this patient was suffering from herpetic stomatitis and pharyngitis.

Course. On the day following the patient's admission to the hospital, his temperature was normal, but there was no change in the condition of the mouth. The mouth lesions were treated with topical applications of gentian violet. On November 8th the white cells numbered 7,700. The lesions were slowly resolving, but enough discomfort persisted to prevent the taking of solid food. By November 11th the lesions had practically disappeared and the patient was discharged. There has been no recurrence of the herpes up to the present time.

Miss C. W., J. H. H. 46136, a student nurse, aged 22, entered the Medical Clinic on January 2nd, 1933, complaining of a "sore throat" of two days duration. With the onset of this affection she suffered from "chills and fever," headache and anorexia. On the following day she felt weak and experienced generalized aching. Profuse sweats occurred during the night. On the day of admission malaise was present and the glands in her neck were enlarged and tender.

Physical examination. The patient was well nourished and seemed com- 
fortable. The temperature, pulse and respirations were normal. A faint, generalized erythema was present. The ears, eyes and nose were normal, as were also the lips, gums, buccal mucous membranes and tongue. A discrete vesicular eruption was present over the left anterior pillar and over a right tonsillar tag. The vesicles ranged in size from two to four millimeters and were surrounded by small areas of very hyperemic mucous membrane. The entire throat was mildly erythematous and the lymphoid follicles on the posterior pharyngeal wall were hypertrophied. The regional lymphnodese were moderately enlarged and tender. Otherwise the physical examination was normal.

Laboratory data. Urine normal. Red blood cells 4.9 million. Hemoglobin 100. White blood cells 7,050. Differential count-polymorphonuclears 65 , eosinophiles 1 , basophils 1 , lymphocytes 29 , monocytes 4 . Wassermann reaction negative. Throat culture-staphylococcus albus and aureus.

Impression. Herpetic pharyngitis.

Course. The temperature, pulse and respirations remained normal throughout the patient's stay in the hospital. By January 6th the throat had improved and on the following day the patient was discharged from the hospital. No local treatment was used in this instance. There has not been any recurrence of the affection to date.

\section{Experimental studies.}

Miss C. K. No studies were made because the nature of the throat affection was not suspected until after the vesicles had disappeared.

Mr. M. T. Upon November 4th, the cap of a tense vesicle was removed with biting forceps and this material was rubbed into the scarified left corneae of two rabbits. Within twenty-four hours a localized injection of the sclera was observed and after a short time one could see minute vesicles along the lines of scarification with the aid of a hand lens. By November 7th a full blown, steamy keratitis was manifest in both animals. At this point, rabbit Number 1 was killed, the left cornea was removed and then ground in a sterile mortar with a small amount of sterile physiological saline solution. The left scarified corneae of rabbits Numbers 3 and 4 were inoculated with the ground material.

On the 12th of November rabbit Number 2 was hypersensitive and circled definitely to the left. Three days later this animal was extremely hypersensitive, circled to the left, showed marked salivation and retention of urine, ran blindly into objects and had an accelerated respiratory rate. Its temperature was $106.8^{\circ} \mathrm{F}$. The rabbit was killed and its brain carefully removed with sterile precautions. A part of the brain was placed in Zenker's acetic fluid, a second portion was cultured in aerobic and anaerobic media, and the remaining bit was ground up in sterile physiological saline solution and the brain suspension was inoculated into the scarified left cornea of a guinea pig. This animal developed a typical keratitis and on the fourth day after inoculation showed characteristic signs of encephalitis. It was then killed and its brain was placed in Zenker's acetic fluid. 
Rabbits Numbers 3 and 4 both developed keratitis within twentyfour hours of inoculation and showed definite signs of encephalitis on the seventh day. At that time they were killed and their brains were placed in Zenker's acetic fixing fluid. Histological sections stained with Mallory's eosin-methylene blue stain were made of the fixed tissues. Examination of these sections showed in each instance the severe, infiltrative meningoencephalitis and the acidophilic intranuclear inclusions which are characteristic of herpetic encephalitis in laboratory animals.

Miss C. W. On January 4th, the top of a tense vesicle was removed and was rubbed on the scarified cornea of a rabbit. By January 6th a definite keratitis was present and on the following day the animal was killed and the infected cornea removed. Part of this cornea was placed in Zenker's acetic fluid and the remainder was used to inoculate the scarified cornea of a second rabbit. This animal developed keratitis within two days and showed signs of encephalitis on the eighth day, at which time it was killed and its brain placed in Zenker's acetic fluid. Histological sections stained with Mallory's eosin-methylene blue stain were made of the fixed tissues. The cornea of the first rabbit showed a severe infiltrative keratitis with rare intranuclear inclusion bodies. Evidently the process had progressed beyond the stage most favorable for the finding of inclusion bodies. A severe meningoencephalitis was present in the second rabbit and numerous brain cells showed the acidophilic intranuclear inclusion bodies which are considered to be typical of herpetic infection.

\section{The clinical course of herpetic stomatitis and pharyngitis}

In all of our cases the onset was slow and the first symptom observed was either a sore mouth or sore throat. Shortly after the onset, headache and malaise accompanied by sensation of "chills and fever" appeared. Sweating was often marked. It was not possible in any of our cases to determine the relation of the appearance of the herpetic lesions to the onset of symptoms. Nausea and vomiting did not occur. As the disease progressed the symptoms became more intense. In all three individuals generalized aching was present at one time or the other. Two patients had a definite fever when admitted to the Ward. These two also had labial herpes and the lesions were widespread in their mouths. None of our cases developed skin lesions. All had white blood cell counts below 8,000 on entry. The differential formulae were normal. Treatment other than palliative seemed to be of little value as the disease is self limited. None of our patients gave a history of susceptibility to herpes and none have had a recurrence of the infection.

We were able to isolate a virus which produced the typical clinical syndromes of herpetic keratitis and encephalitis in rabbits and guinea 
pigs from the vesicles in two of three patients. Histological preparations of the corneae and brains from the infected animals showed the acidophilic intranuclear inclusions which are considered to be characteristic of herpetic infections.

It is very likely that herpetic affections of the mouth and throat are more common than we suspect. It seems curious that a disease apparently so well known and so frequently recognized in the last century should have become rare. It is probable that if more attention is paid to the clinical appearance of "sore throats," many of them will be recognized as being herpetic in origin.

\section{SUMMARY}

Three cases of herpetic pharyngitis and stomatitis have been described and discussed. A virus corresponding to the virus of herpes simplex was isolated from the lesions in two of the three cases.

\section{BIBLIOGRAPHY}

1. Gubler, A., Bull. Soc. méd. d. hôp. de Paris. I Serie, Tome I, 1858, pp. 386-413. Memoire Sur L'Herpes Guttural (Angine Couenneuse Commune) Et Sur L'Opthalomie Due A L'Herpes De La Conjonctive.

2. Trousseau, A., Clinique Médicale. Tome I, Paris, 1861, pp. 431-440. Angines Couenneuses.

3. Savage, G. H., Lancet, 1883, i, 95 . Epidemic of Herpetic Fever.

4. Youmans, J. B., South. M. J., 1932, xxv, 228. Herpetic Fever with Stomatitis: Report and Discussion of a Case in which the Virus was Isolated. 